\title{
Dissatisfaction and Profile of Dissatisfied Consumers: A Case Study of Mobile Telecommunication Network Consumers in Nigeria
}

\author{
Anyanwu Hilary Chinedu ${ }^{1}$, Sharifah Azizah Haron ${ }^{1}$, Syuhaily Osman ${ }^{1} \&$ Hilary Faith Hayatu ${ }^{2}$ \\ ${ }^{1}$ Department of Resource Management and Consumer Studies, Faculty of Human Ecology, Universiti Putra \\ Malaysia, Malaysia \\ ${ }^{2}$ School of Management, Faculty of Business and Law, Anglia Ruskin University, United Kingdom \\ Correspondence: Anyanwu Hilary Chinedu, Department of Resource Management and Consumer Studies, \\ Faculty of Human Ecology, Universiti Putra Malaysia, 43400 UPM Serdang, Selangor Darul Ehsan, Malaysia. \\ E-mail: chineduhilary@yahoo.com
}

Received: March 12, 2020

doi:10.5539/ijbm.v15n5p155
Accepted: March 30, 2020

Online Published: April 17, 2020

URL: https://doi.org/10.5539/ijbm.v15n5p155

\begin{abstract}
This research paper examined the dissatisfaction of Mobile telecommunication network (MTN) consumers in Nigeria. The researchers used expectancy disconfirmation theory (EDT) to argue that with high and prolonged consumer dissatisfaction, educated MTN consumers are prone to exit their service chain for other telecom companies. Contrary to MTN's promises upon entry into the Nigerian telecom market, its consumers have been groaning against substandard services offered to them by MTN. Adequate supply, stability, and maintenance/hitch free services lead to consumer satisfaction, while deficiency of the stated factors aggravates consumers, thus consumer dissatisfaction. This quantitative research utilized a cross-sectional design and adopted a stratified sampling technique to incorporate 385 MTN consumers in Lagos, Nigeria. IBM SPSS version 22 was used for the data analysis. The data set consisted of $58.2 \%$ males and $41.8 \%$ females. Descriptive statistics found that $43.9 \%$ of MTN consumers were highly dissatisfied while $56.1 \%$ were lowly dissatisfied. A Chi-square test revealed that only educational level is significantly associated with dissatisfaction among the six selected background variables. Also, logistic regression showed age, educational level, and religion as significant predictors of high dissatisfaction among consumers. Educated consumers tend to sensitize service outcomes more than uneducated ones as a result of their wealth of information. Older (aged) and religious consumers will also evaluate marketing episode critically more than younger and non-religious ones. Results further imply that consumers' educational level is a catalyst of expectancy disconfirmation theory in service sectors. MTN or similar commercial enterprises should focus on the causes of dissatisfaction and strategize on how to ameliorate the dissatisfaction level among their consumers. Firms should embark on promotional offers and other stimuli activities to regain their consumers' trust and loyalty; hence, it will extend their market share and dominance.
\end{abstract}

Keywords: dissatisfied consumers, dissatisfaction, mobile telecommunication network, MTN consumers

\section{Introduction}

Mobile telecommunication network (MTN) consumers in Nigeria have been engulfed with substandard services contrary to the promises of MTN upon entry into the Nigerian telecommunication market. High prevalence of predicaments towards MTN consumers for many years devoid of ultimate way out underscored the importance of the current paper, "dissatisfaction and profile of dissatisfied MTN consumers in Nigeria". MTN launched the first mobile call in Nigeria on $16^{\text {th }}$ May 2001 following the globally lauded Nigerian telecom market liberalization. The firm has dominated the Nigerian telecom market with over 61 million consumers out of over 148 million subscribers in Nigeria (NCC, 2016). According to mobi-thinking (2013), China, India, United States, Indonesia, Brazil, Russia, Nigeria, Pakistan, Japan, and Germany are the top 10 countries in the world with over 100 million mobile subscribers each. Although Nigerian is placed in the top ten consumers of mobile telecom services in the world, Nigerian mobile consumers grunt continually for unhealthy service delivery by MTN and their likes (Samuel and Olatokun, 2014).

Reciprocation of MTN to Nigeria has been seen as a double-barreled statement by Nigerian consumers relative to consumer's patronage and outcry for inappropriate and unethical services. Among the numerous problems of MTN consumers are charged uninvited caller tunes (Timothy, 2015), and high tariff and network fluctuations 
(Donu, 2011). Several studies on consumer dissatisfaction and telecommunication services have been conducted in Western and Asian countries with little focus in African context especially Nigeria, (see: Turel and Serenko, 2006; Gerpott, Rams, and Schindler, 2001; Bolton, 1998). Besides, there has been no study that investigated the factors that predict the likelihood of consumers to be highly dissatisfied to the best of the researcher's knowledge. This implies that there is a dearth of literature on this concept in developing countries, including Nigeria which ought to be covered by research. Sequel to that, this research paper sought to actualize the following objectives; (i) to measure the dissatisfaction of MTN consumers in Nigeria. (ii) To construct the profiles of dissatisfied MTN consumers in Nigeria. (iii) To determine the factors that predict the likelihood of consumers to be highly dissatisfied.

Previous studies have suggested network quality, customer care, price, and personal benefits as the four major factors that drive the consumer value of mobile services (see: Bolton, 1998; Danaher and Rust, 1996). Gerpott, Rams, and Schindler (2001) found that consumer satisfaction drives consumer loyalty which in turn has impacts on consumer retention; Kim, Park, and Jeong (2004) postulated that call quality, value-added services, and consumer enhancement are significantly related to consumer satisfaction; Turel and Serenko (2006) echoed that service quality and perceived value are the major predictors of consumer satisfaction with mobile services; and Falilat, Salman and Oluwayom (2014) found that consumer satisfaction is significantly related to increased market share of a telecommunication organization. The above studies stand to cement the fact that poor network quality, unfriendly or inefficient customer care, and regular increments of service rates are seen as major causes of consumer dissatisfaction among telecom consumers. Hence, a reverse of the service characteristics that foster consumer satisfaction yields dissatisfaction. These anomalies lead to consumer dissatisfaction which aggravates mistrust, disloyalty and switching to competitor services.

\subsection{Theoretical Background}

Expectancy disconfirmation theory (EDT) as hypothesized by Oliver $(1980,1977)$ is a cognitive theory that sought to explain post-purchase or post subscription satisfaction as a function of expectations, perceived performance, and disconfirmation of beliefs. According to Patrick-Akpan (2018), EDT is simply the resultant satisfaction/dissatisfaction of combining expectations with perceived performance after consumption. EDT emanated from a study for antecedents of satisfaction (Anderson and Sullivan, 1993), and stresses on how people become satisfied/dissatisfied as a result of the disparity between their expectations before product purchase, in this context, expectation before subscription to MTN service, and perceived MTN service. Thus, EDT is believed to be a product of human comparison of expectation and performance of a service process. Oliver (1980) noted that during comparison, better-than-expected performances result in satisfaction, while worse-than-expected outcomes result in dissatisfaction. Resultant to this, EDT has been applied in several telecommunication service satisfaction/dissatisfaction studies across Nigeria (Cf. Abubakar, 2016; Izogo, 2017), and is believed to be apt for the present study. Therefore, EDT is adopted as a theoretical background for insightful understanding of consumer dissatisfaction among MTN consumers in Nigeria.

\section{Literature Review}

Over forty years ago, the concept of consumer dissatisfaction has received extensive consideration from researchers. Several empirical studies have taken place to draw down the gap in many consumer hitches and minimize consumer swapping (see: Nimako and Ntim, 2015; Kotler and Keller, 2012; Sathish, Kumar, Naveen, and Jeevanantham, 2011). Modern business organizations have adopted a customer-centric marketing strategy to maintain and extend close relationships with profitable consumers through highlighting of relative frequencies of various consumer problems (Jaakkola and Alexander, 2014; Kotler and Keller, 2012). Business organizations with this strategy are likely to maintain their market share in the sector, but organizations without consumer-minded strategies tend to lose their consumers. As a result of that, consumers change to other service/product providers/manufacturers in protest to their dissatisfaction.

There may be no outright dissatisfaction without comparing the current products/services with others. Given this, Kotler (2001) opined that if a consumer's expectations are met, the consumer becomes satisfied, if the expectations are surpassed, he/she becomes delighted, but when they are not met, the consumer is dissatisfied. While consumer satisfaction/dissatisfaction has not been homogenously defined by researchers as they have seen it from different perspectives (Gloria, 2011), there is no doubt that satisfaction/dissatisfaction entails pre and post evaluations of expectations and performances respectively. Consumer satisfaction/dissatisfaction is a multifaceted concept as its study has utilized divergent methods (Kanji and Moura, 2002; Barsky, 1995). Consumer satisfaction/dissatisfaction is an affective response towards a product/service outcome relative to various pre-acquisition standards in the course of usage or after utilization (Halstead, Hartman, and Schmidt, 
1994); an attitude or appraisal decision wavering laterally on the hedonic variety aimed at the product/service that is assessed after use (Mano and Oliver, 1993). Thus, consumers' satisfaction/dissatisfaction in a service context is hinged on the ability of a service provider to ensure that their service performance is equal to or greater than consumers' expectations; implying that comparison between expectation and performance influences consumers' satisfaction/dissatisfaction judgment.

Given Kotler's concept, consumer dissatisfaction refers to the consumer's perception that his/her expectations have been cut short or inadequately met. Dissatisfaction may also be seen as a by-product of contemplating the shortfalls on a consumer's expectations after a buying episode. The above authors have conceptualized satisfaction/dissatisfaction in their best terms with some important components missing in their definitions. From a conceptual point of view, dissatisfaction is a cognitive and affective process in response to a company's shortfall which is triggered by a comparison of expected service performance and actual service performance during or after consumption. The dissatisfaction of mobile telecommunication network (MTN) consumers is caused by the countless occurrences of irregularities with services deprived of ultimate answer (Chinedu, Haron, and Osman, 2017) which is contrary to their promises before entry into the Nigerian telecom market (Chinedu, Haron, and Osman, 2016), and evaluation of their pre-purchase expectations and services delivered to them. This makes Kotler (2001) postulation a basis for consumer-minded firms to strategize and ameliorate the discontent of their consumers. Hence, if consumers' expectations are met, they are satisfied, and if surpassed, they become delighted. Thus, a growing need for MTN to always try and avoid the expectations of their consumers from not being met. Dissatisfaction causes disloyalty among consumers and is detrimental to business organizations. Because of this, it is crucial to review factors that contribute to consumers' dissatisfaction.

\subsection{Factors That Contribute to Dissatisfaction among Consumers}

Past studies have shown that several factors may contribute to negative disparity among consumers (see; Akash, 2015; Gr'nhaug \& Johan, 1980). According to the authors, knowledge, perceived importance, and unfulfilled promises are the major causes of dissatisfaction among consumers. With full knowledge of other buying alternatives from what a consumer had purchased, there may be no dissatisfaction hence; unlikely to compare the buying alternatives (Akash, 2015; Gr'nhaug \& Johan, 1980). In a situation where the consumer lacks the knowledge of other marketing options, the tendency of negative disparity becomes inevitable. Consumers are expected to be aware of various network plans they subscribe to in the telecom market. This is to mitigate the unnecessary level of comparing subscription alternatives with competitor network providers which may trigger dissatisfaction among consumers.

Notably, consumers buy or subscribe to products/services according to their importance. With the high perception of the importance of the product/service, there will be more attention to the product/service and thus, a serious perception of the negative discrepancy between expectation and realized performance (Akash, 2015). Given the importance and urgency to make some phone calls, a subscriber is bound to be dissatisfied in response to a fluctuating network which obstructed his/her intent to deliver a message through the phone call. In some cases, the consumer will try to recharge his/her phone with a calling card but the fluctuating network would not support the reload exercise. Although nature (weather) contributes to the efficiency of a telecom network service, consumers hardly accept it as an excuse for unhealthy services. Such a situation will ultimately lead to consumer dissatisfaction.

Furthermore, unfulfilled advertising promises are also on a high level in the list of factors that causes dissatisfaction among consumers. Some advertisements by firms are not obtainable in the list of products/services offered by firms. Such adverts are commercial stimuli and may lead consumers to higher expectations which are not realizable. Unfulfilled advertisements are parts of desperate marketing antics that trigger a high probability of dissatisfaction. In any case, firms should be real to consumers and advertise only the products/services available in their domain. The psychology of consumers should always be taken care of by firms as continuous failure may lead to negative reactions from consumers.

\subsection{Effects of Demographic Variables on Consumer Dissatisfaction}

Several marketing forces and situational factors are seen as influencers of satisfaction/dissatisfaction among consumers. Notwithstanding, consumer satisfaction/dissatisfaction remains inextricably correlated with consumers' demographic background. Previous studies have examined the effects of demographic background on the perception of service outcomes by consumers with varying opinions. For example, Serin, Balkan and Dogan (2013) and Jabulani (2001) have contradicting views on the effects of educational level on perceived satisfaction/dissatisfaction; Mirzagoli and Memarian (2015) asserted that women are more satisfied than men contrary to the findings of Jabulani (2001) which found no significant relationship with gender. 
Gender: Correlation exists between gender and perceived satisfaction among public and private bank customers in Turkey (Serin, Balkan and Dogan, 2013). A study of patients' satisfaction in medical care at Malik Khalid University Hospital Riyadh, Saudi Arabia conducted by Al-Doghaither (2004) concluded that women are more satisfied than men. Mirzagoli and Memarian (2015) found similar results on customer satisfaction towards the use of ATM. Mirzagoli and Memarian (2015) suggested that subjective criteria and expectations of men and women are different, and thus, gender ought to be considered in marketing policy than designing the marketing plan. On the contrary, Jabulani (2001) opined that gender has no significant relationship with perceived satisfaction. Mburu (2014) stated that gender does not affect customer satisfaction. Given these varying opinions, the impacts of gender on consumer satisfaction/dissatisfaction remains unclear, hence, researchers are yet to come up with a consensus view. This lends support to the continued investigation of the effects of gender on satisfaction/dissatisfaction.

Age: Relying on Serin, Balkan and Dogan (2013), age is significantly related to perceived satisfaction. In a study of demographic factors and customer perception of hotel service quality delivery in Jamaica, Jabulani (2001) found that age affects the quality of service perception by the customer. In a different study, Nischay, Sankpal, and Upamannyu (2014) found that age does not affect customer satisfaction. The finding from Nischay, Sankpal, and Upamannyu (2014) which is contrary to other authors necessitates a replication of the investigation. However, service quality should be improved on aged (older) customers/patients given their ability to evaluate situations more critically than younger customers.

Educational level: Educational qualification has a significant effect on customer satisfaction and loyalty intention (Nischay, Sankpal, and Upamannyu, 2014). The study of Kenyan banks by Mburu (2014) equally found that educational level is significantly associated with customer satisfaction. Also, Jabulani (2001) found that educational level affects perception of hotel customers' satisfaction. On the contrary, Serin, Balkan and Dogan (2013) found no significant relationship with educational level and perceived satisfaction among public and private bank customers in Turkey. Service providers should review the quality of services provided to educated customers and upgrade to their taste. Educated customers tend to be easily dissatisfied in a marketing exercise due to their knowledge of various options in the market. The continued varying views of these authors call for further examination of the effects of educational level on customer satisfaction/dissatisfaction.

Religion: Religion is being deemed 'unclear or fuzzy', thus, under-researched (Delener, 1994). Despite Delener's (1994) assertion of the fuzzy nature of religion, the effect of religion on customer or consumer satisfaction/dissatisfaction has remained under-researched due to its delicate nature in society. Reidenbach and Robin (1990) suggested that religion can have a major influence on ethical decision making, specifically on the formation of ethical judgment. They further stated that consumers use more than one justification when making ethical decisions and that the relative significance of these reasons is a function of the particular situations awaiting the consumer. Religious commitment is a notable determinant of the importance consumers place on certain products/services' evaluative criteria (Essoo and Dibb, 2004). Religious attachment is personal and is determined by the level a consumer adheres to religious beliefs and integrates them into his/her market evaluative judgments. The effect of religion on consumer dissatisfaction is therefore unclear pending the result of investigative studies.

Marital status: A previous study conducted in Kenya revealed that marital status is not significantly associated with customer satisfaction Mburu (2014); married and single employees are found to have no significant difference in terms of job satisfaction (Azim, Haque and Chowdhury, 2013). On the other hand, Serin, Balkan and Dogan (2013) found a relationship between marital status and perceived satisfaction among public and private bank customers. Mirzagoli and Memarian (2015) concluded that married customers are more satisfied than single customers, citing that a change of status from single to married increases satisfaction by $39 \%$. This result shows that single customers will be more dissatisfied than married customers, and thus highlights the need for managers and service providers to improve service delivery to single customers.

Level of income: Monthly income is significantly associated with customers' satisfaction Mburu (2014). According to Mirzagoli and Memarian (2015), Al-Doghaither (2004) found that wages have a low impact on satisfaction. Consumers' level of income is likely to drive satisfaction/dissatisfaction due to the changing tastes and preferences of consumers, and inflation. As the prices of goods/services increases, consumers with higher income will cope and become somewhat satisfied than low-income earners. This will draw a baseline between the higher income and low-income consumers and thus affect their dissatisfaction. 


\section{Methodology}

\subsection{Design, Location, and Sampling}

This is a quantitative research that utilized a cross-sectional method to investigate the overall MTN consumers in Nigeria (about 61,200,000). The sample size is calculated using Cochran's (1977) sample size formula.

$$
\mathrm{n}=(\mathrm{t})^{2} *(\mathrm{p})(\mathrm{q}) /(\mathrm{d})^{2}
$$

$\mathrm{n}=$ Sample size, $\mathrm{t}=$ value of selected alpha level (1.96 i.e. $95 \%$ confidence level), $\mathrm{P}=$ estimated proportion of an attribute present in the population (.5), $\mathrm{q}=1-\mathrm{p}$ (estimate of the variance), and $\mathrm{d}=$ is the acceptable margin of error or confidence interval (.05) in other words \pm 5 .

$\mathrm{n}=1.96^{2} \times .5 \times 1-.5 \div .05^{2}$

$\mathrm{n}=3.841 \times .25 \div .0025$

$\mathrm{n}=.960 \div .0025$

$\mathrm{n}=384.1$

Sample size $(\mathrm{n})=384.1 \approx 385$.

This research utilized a stratified sampling procedure. A stratified sampling method is a sampling practice whereby an investigator groups the sampling frame in such a manner that the number within a stratum (group) is homogenous for the features by which it is grouped (Ranjit, 2011). A stratified sampling procedure is beneficial to this research because it granted the researchers the opportunity to spread the collection of data to three areas of the study location via stratification, and thus covered a wider view of the subjects being investigated. Besides, a stratified sampling procedure does not accommodate bias in the selection of respondents and fosters a robust collection of data (Chinedu et al., 2017).

\subsection{Data Collection}

The researchers collected data for the present study via a survey with self-administered questionnaires in the Festac town of Lagos, Nigeria. The consumers within $24^{\text {th }}$ road, $23^{\text {rd }}$ road, and $5^{\text {th }}$ avenue were given questionnaires to give their opinions based on the above-stated sampling technique.

\subsection{Instrumentation}

Measuring instrument of the study was a structured questionnaire which consisted of closed-ended questions for consumers' demographic characteristics and tabularized statements that required the respondents' views on dissatisfaction. Consumer dissatisfaction was measured using twelve statements on a five-point Likert scale, from $1=$ strongly disagree to $5=$ strongly agree. Among the twelve statements, seven were adapted from Westbrook and Oliver (1981), while the other five were adopted from Chinedu (2017). The research subjects were queried about their feelings during and/or after using MTN services by marking the appropriate box. Examples of the statements are; I have enjoyed MTN service; I feel extorted with MTN's high call charges; I am satisfied with MTN because they give back to society.

The instrument's reliability was assessed using Cronbach alpha, and the alpha value of dissatisfaction was .808 . An alpha value greater than .70 is adequate for research purposes Hair et al. (1995), implying that the research instrument was reliable. Content validity was used to validate the instrument; the instrument was given to an expert in the field to check if it contains the necessary statements that could measure the construct under investigation.

\subsection{Data Analysis}

Data was analyzed using IBM SPSS version 22. Demographic characteristics of the respondents were assessed with descriptive statistics such as frequency, and percentage. Also, descriptive statistics were utilized in measuring levels of consumer dissatisfaction. Chi-square test for independence was used to ascertain the profile of dissatisfied MTN consumers, while logistic regression was employed to determine the factors that predict the likelihood of consumers to be highly dissatisfied.

\section{Findings and Discussions}

\subsection{Sample Characteristics}

Table 1 shows that a higher percentage (58.2\%) of the respondents are males as they comprised of 224 out of 385 , while females consisted of $161(41.8 \%)$. Respondents within the age category of 18 to 27 years old are higher in number (47\%), followed by respondents within the age group of 28 to 47 years old (41\%), while respondents that are more than 47 years old accounted for $(11.9 \%)$. Almost three-quarter $(74.3 \%)$ of the respondents had tertiary 
education, while respondents that attained secondary education were $22.9 \%$. It is interesting to note that respondents with primary education and those that never attended school accounted for $2.1 \%$ and $.8 \%$ respectively, implying that over $97 \%$ of the respondents are educated to secondary or tertiary education.

Continuing, more than half of the respondents (63.9\%) are single; about $35.6 \%$ are married, while respondents that either divorced, lost their partner, or religious people that will not marry constituted $.5 \%$. Also, Christian respondents were more than half (57.1\%), while the remaining (42.9\%) are Muslims. This is an indication of the dominance of Christianity and Islam in Lagos Nigeria as no other religion was identified by respondents of the present study. More so, about $44.2 \%$ of the respondents earn less than eighteen thousand naira $(\# 18,000)$ per month, while $30.9 \%$ of the respondents earn between $\# 18,000$ and $\# 75,000$. Surprisingly, only $24.9 \%$ of the respondents earn more than $\# 75,000$ per month; thus, it means that majority of the respondents are low-income earners. This further reveals that most Nigerians earn below 200US\$ per month.

Table 1. Respondent's background information

\begin{tabular}{|c|c|c|}
\hline Variables & Frequency (n) & Percentage (\%) \\
\hline \multicolumn{3}{|l|}{ Gender } \\
\hline Male & 224 & 58.2 \\
\hline Female & 161 & 41.8 \\
\hline \multicolumn{3}{|l|}{ Age } \\
\hline 18-27years old & 181 & 47.0 \\
\hline 28-47years old & 158 & 41.0 \\
\hline More than 47 years old & 46 & 11.9 \\
\hline \multicolumn{3}{|l|}{ Educational level } \\
\hline Never attended school & 3 & .8 \\
\hline Primary school & 8 & 2.1 \\
\hline Secondary school & 88 & 22.9 \\
\hline Tertiary institution & 286 & 74.3 \\
\hline \multicolumn{3}{|l|}{ Marital status } \\
\hline Single & 246 & 63.9 \\
\hline Married & 137 & 35.6 \\
\hline Others & 2 & .5 \\
\hline \multicolumn{3}{|l|}{ Religion } \\
\hline Christian & 220 & 57.1 \\
\hline Muslim & 165 & 42.9 \\
\hline \multicolumn{3}{|l|}{ Level of income } \\
\hline$<\# 18,000$ & 170 & 44.2 \\
\hline$\# 18,000-\# 75,000$ & 119 & 30.9 \\
\hline More than $\# 75,000$ & 96 & 24.9 \\
\hline
\end{tabular}

Note. \# =Naira (Nigeria's local currency).

\subsection{Measurement of MTN Consumers' Dissatisfaction}

Results from Table 2 show that 216 (56.1\%) respondents out of the sample size (385) are in a low category while $169(43.9 \%)$ respondents are in the high category. The respondents in the low category are not totally dissatisfied, in other words, they are somewhat satisfied with MTN products and services. This implies that $43.9 \%$ of the respondents in the present study are highly dissatisfied with MTN products and services. The remaining $56.1 \%$ are somewhat satisfied with MTN services. This is an indication that slightly more than half of MTN consumers in Nigeria are averagely happy with MTN products and services. This result is supported by the Nigerian consumer satisfaction survey's final report (2012) which stated that over 53\% of MTN consumers are satisfied with MTN services. 
Table 2. Measurement of MTN consumers' dissatisfaction

\begin{tabular}{llll}
\hline Category & Score range & Frequency & Percentage (\%) \\
\hline Low & $12-36$ & 216 & 56.1 \\
High & $37-59$ & 169 & 43.9 \\
Total & & 385 & 100.0 \\
\hline
\end{tabular}

\subsection{Profile of Dissatisfied MTN Consumers}

The demographic characteristics of the respondents have been calculated among 216 low and 169 high dissatisfied MTN consumers as shown in Table 3. In terms of gender, the sample indicated that males were 130 low, and 94 high dissatisfied respondents which totaled to 224 (58.2\%) while females were 86 low, and 75 high dissatisfied respondents which summed up to $161(41.8 \%)$. A Chi-square test between gender and dissatisfaction was performed and the test found a non-significant value $(\mathrm{p}=.426)$ for gender characteristics. There is no significant association between gender and dissatisfaction among MTN consumers in Nigeria. The result is consistent with the findings of Mburu (2014) whose result stated that gender does not affect customer satisfaction/dissatisfaction.

In terms of age, 18-27years group had 92 low and 89 high dissatisfied respondents which amounted to 181 (47.0\%); 28-47years had 93 low and 65 high respondents which summed up to 158 (41.0\%); more than 47years group had 31 low and 15 high dissatisfied respondents which totaled to $46(11.9 \%)$. When a Chi-square test was conducted between age and dissatisfaction, a non-significant Chi-square value $(p=.086)$ was found between them. The result showed that there is no significant association between age and dissatisfaction. The result is in tandem with Nischay, Sankpal, and Upamannyu (2014) who found that age does not affect customer satisfaction/dissatisfaction. Anything good is adored by all irrespective of age, and bad things are disliked in all quarters. Age being insignificant to dissatisfaction is attributed to the poor network quality of MTN services which is experienced by every consumer beyond age limits. The poor service aggravates everyone (young and older consumers) not minding the age group.

Also, the educational level which comprised of below tertiary education and tertiary education groups was tested with Chi-square against dissatisfaction. Below tertiary education had 68 low and 31 high dissatisfied respondents which accounted for $99(25.7 \%)$, and tertiary education had 148 low and 138 high dissatisfied respondents which gave $286(74.3 \%)$. The Chi-square test found a significant value $(\mathrm{p}=.005)$ for educational level characteristic. This shows that there is a significant association between educational level and dissatisfaction. This result is supported by Jabulani (2001) and Mburu (2014). The saying that "information is power" substantiates the significance of educational level against dissatisfaction. Information is mainly achieved through or with education. Media and other sources of information are only useful to those that can read and understand, thus making judicious use of an educational level to know when an anomaly occurs and to compare situations with other firms or countries.

In terms of current marital status, married respondents were 78 low and 59 high dissatisfied which summed up to 137 (35.6\%); and single respondents were 138 low and 110 high dissatisfied which made a total of $248(64.4 \%)$. A Chi-square test between current marital status and dissatisfaction produced a non-significant result $(\mathrm{p}=.891)$. Based on this result, there is no significant association between current marital status and dissatisfaction. Consistent with this result is Azim, Haque, and Chowdhury (2013) whose result indicated that married and single employees are found to have no significant difference in terms of job satisfaction. Also, Mburu (2014) found no significant association between marital status and customer satisfaction/dissatisfaction. Dissatisfaction as an unpleasant phenomenon does not segregate in its occurrences. The same moody state of a single dissatisfied person applies to a married person. In other words, both married and single individuals are prone to dissatisfaction with a poor service depending on the importance the individual attached to the situation.

On the religion of respondents, Christians were 114 low and 106 high dissatisfied respondents which equaled to $220(57.1 \%)$ while Muslims were 102 low and 63 high dissatisfied respondents totaling to $165(42.9 \%)$. When a Chi-square test between religion and dissatisfaction was conducted, a non-significant value $(p=.064)$ was obtained. There is no significant association between religion and dissatisfaction. The two dominant religions in Nigeria (Islam, and Christianity) have always stood for the right philosophies of life and business, thus, they both impact the ideology of getting it right in an appropriate manner and context to their faithful. Religious laws and principles stand as a watchword for the consumers which guide them in certain decision making. This is undoubtedly the reason why religion is not significant to dissatisfaction. 
Furthermore, the income level of the respondents was classified into three groups, namely; $<\# 18,000 ; 18,000$ $\# 75,000$; and more than $\# 75,000$. Less than \#18,000 group had 94 low and 76 high dissatisfied respondents which constituted 170 (44.2\%); 18,000 to \#75,000 group had 63 low and 56 high dissatisfied respondents which summed up to 119 (30.9\%); and more than \#75,000 group accounted for 96 (24.9\%), that is 59 low and 37 high dissatisfied respondents. A Chi-square test between the level of income and dissatisfaction was conducted. A non-significant value $(p=.439)$ was obtain. There is no significant association between level of income and dissatisfaction. The non-significant result of income level to dissatisfaction is attributed to frustrations and difficulties all the income groups passed through. Whenever the network fluctuates or poor services are being experienced, it affects consumers indiscriminately, and substantiates the irrelevance of income level; hence, every income group is affected.

Table 3. Cross-tabulation of dissatisfied MTN consumers with background variables

\begin{tabular}{|c|c|c|c|c|c|c|c|c|}
\hline \multirow{3}{*}{ Demographic profile } & \multicolumn{2}{|c|}{ Low } & \multicolumn{2}{|c|}{ High } & \multicolumn{2}{|c|}{ Total } & \multirow{3}{*}{$\chi^{2}$} & \multirow{3}{*}{$\mathbf{p}$} \\
\hline & $\mathbf{n}$ & $\%$ & $\mathbf{n}$ & $\%$ & $\mathbf{n}$ & $\%$ & & \\
\hline & 216 & 56.1 & 169 & 43.9 & 385 & 100 & & \\
\hline \multicolumn{9}{|l|}{ Gender } \\
\hline Male & 130 & 58.0 & 94 & 42.0 & 224 & 58.2 & \multirow{2}{*}{.635} & \multirow{2}{*}{.426} \\
\hline Female & 86 & 53.4 & 75 & 46.6 & 161 & 41.8 & & \\
\hline \multicolumn{9}{|l|}{ Age } \\
\hline $18-27 y r s$ old & 92 & 50.8 & 89 & 49.2 & 181 & 47.0 & \multirow{3}{*}{4.913} & \multirow{3}{*}{.086} \\
\hline $28-47 \mathrm{yrs}$ old & 93 & 58.9 & 65 & 41.1 & 158 & 41.0 & & \\
\hline More than $47 y r s$ old & 31 & 67.4 & 15 & 32.6 & 46 & 11.9 & & \\
\hline \multicolumn{9}{|l|}{ Educational level } \\
\hline Below tertiary & 68 & 68.7 & 31 & 31.3 & 99 & 25.7 & \multirow{3}{*}{7.894} & \multirow{3}{*}{.005} \\
\hline education & & & & & & & & \\
\hline Tertiary education & 148 & 51.7 & 138 & 48.3 & 286 & 74.3 & & \\
\hline \multicolumn{9}{|l|}{$\begin{array}{l}\text { Current marital } \\
\text { status }\end{array}$} \\
\hline Married & 78 & 56.9 & 59 & 43.1 & 137 & 35.6 & \multirow{2}{*}{.019} & \multirow{2}{*}{.891} \\
\hline Single & 138 & 55.6 & 110 & 44.4 & 248 & 64.4 & & \\
\hline \multicolumn{9}{|l|}{ Religion } \\
\hline Christian & 114 & 51.8 & 106 & 48.2 & 220 & 57.1 & \multirow{2}{*}{3.433} & \multirow{2}{*}{.064} \\
\hline Muslim & 102 & 61.8 & 63 & 38.2 & 165 & 42.9 & & \\
\hline \multicolumn{9}{|l|}{ Level of income } \\
\hline$<\# 18,000$ & 94 & 55.3 & 76 & 44.7 & 170 & 44.2 & \multirow[t]{3}{*}{1.646} & \multirow{3}{*}{.439} \\
\hline $18,000-\# 75,000$ & 63 & 52.9 & 56 & 47.1 & 119 & 30.9 & & \\
\hline More than $\# 75,000$ & 59 & 51.5 & 37 & 38.5 & 96 & 24.9 & & \\
\hline
\end{tabular}

Note. Level of significant is at $\alpha \leq 0.05$.

\subsection{Determination of Factors That Predict the Likelihood of Consumers to Be Highly Dissatisfied}

Direct logistic regression was performed to determine the factors that predict the likelihood of consumers to be highly dissatisfied. For this analysis, respondents that answered others (religious personnel, separated, divorced, and widow/widower) as their marital status are merged with single respondents. The model contained six independent variables (A1=gender, A2 =age, A3=educational level, A4=marital status, A5=religion, and A6=level of income). The full model containing all predictors was statistically significant, $\mathrm{x}^{2}(6, \mathrm{~N}=385)=19.97, \mathrm{p}<$ 0.005. Also, Hosmer and Lemeshow test $\mathrm{x}^{2}(8, \mathrm{~N}=385)=8.62, \mathrm{p}>.05$ supported the model's fit based on criteria set by Pallant (2011). Relying on Pallant (2011), a model is said to be fit if the Hosmer-Lemshow test significant value is greater than .05 (opposite of omnibus tests of model coefficients). Given the fitness of the model, it is an indication that the model was able to distinguish between respondents with high dissatisfaction and low dissatisfaction. The model as a whole explained between 5.1\% (Cox and Snell R square), and 6.8\% (Nagelkerke R squared) of the variance in the dissatisfaction category, and correctly classified $60.8 \%$ of cases.

As shown in Table 4, only three of the independent variables (age, educational level, and religion) made a unique statistically significant contribution to the model. The strongest predictor of high dissatisfaction was A3 (educational level), recording an odds ratio of 1.75. This indicated that respondents who attained tertiary 
education are almost two times more likely to be highly dissatisfied with MTN services than respondents with below tertiary educational level. The odds ratio of .58 was less than 1 and smallest in the model, indicating that for every additional year the respondents were .58 times less likely to be highly dissatisfied after controlling other factors in the model.

The findings imply that age, educational level, and religion are significant predictors of high consumer dissatisfaction. Given the significant role of age in high dissatisfaction, disconfirmation evaluation can be said to rely on the ability of a consumer to figure out how negatively or positively he/she has been rewarded which is the basis of dissatisfaction judgment. In making this ethical judgment on whether a product/service constitutes a high dissatisfaction, consumers' age, educational level, and religion are seen to be the determinant factors among other selected demographic variables. Hence, minor (under-aged) consumers cannot evaluate a situation properly and are not in a better position to conclude certain ethical judgments. In the same vein, uneducated consumers are not adequately informed on the philosophies of interpersonal transactions. An example is a situation where consumers are unable to read and understand the terms and conditions of a service given by an insurance company, such consumers tend to ignorantly sign the agreement and will be highly dissatisfied on realizing the terms later. This is based on the fact that information is power that is easily acquired through education. Similarly, consumers with low religiosity (that is consumers that attach less importance to religion) lack moral formation. This finding demonstrates that moral formation consolidates human philosophy in different aspects of life, especially during decision making. Hence, according to Reidenbach and Robin (1990), religion is likely to affect moral decision making especially during an ethical judgment. When these three variables are high in consumers, there is a tendency of such consumers to be highly dissatisfied after evaluating a marketing episode.

Table 4. Logistic regression model result for demographics and high dissatisfaction

\begin{tabular}{lllllll}
\hline Independent variables & B & S.E & Wald & Exp (B) & \multicolumn{2}{c}{ 95\% C.I for Exp (B) } \\
\cline { 6 - 7 } & & & & & Lower & Upper \\
\hline Gender & .231 & .216 & 1.145 & 1.260 & .825 & 1.923 \\
Age & -.537 & .214 & $6.279^{*}$ & .584 & .384 & .890 \\
Educational level & .560 & .215 & $6.770^{* * *}$ & 1.750 & 1.148 & 2.668 \\
Marital status & -.446 & .286 & 2.426 & .641 & .366 & 1.122 \\
Religion & -.487 & .216 & $5.079^{*}$ & .614 & .402 & .938 \\
Level of income & -.024 & .157 & .023 & .977 & .718 & 1.329 \\
\hline
\end{tabular}

Note. $* \leq .05 ; * * * \leq .01$.

\section{Conclusion and Recommendations}

\subsection{Conclusion}

The study highlighted the concept of dissatisfaction together with factors that trigger it. Facts from the study revealed that less than half of MTN consumers in Nigeria (43.9\%) are highly dissatisfied with their services. The study also depicted the educational level as the only background character that has a significant association with dissatisfaction among MTN consumers in Nigeria. This implies that high interest in tertiary education (over 74\%) among MTN consumers as reflected in the samples' characteristics above tends to influence the level of dissatisfaction among Nigerian consumers. All things being equal, other background characteristics are seen to play a minimal role in consumer dissatisfaction.

Fundamentally, business organizations experiencing a close range of high and low levels of dissatisfaction without a healthy revamp in policies and the core causes of dissatisfaction tend to find their organizational resources dwindling to liquidation level. This implies that with the margin of closeness from the study's inference $(\approx 12 \%)$ between high and low levels of dissatisfaction among MTN consumers, it is pivotal that MTN or any business organization in this situation must resort to total revamp in all sections related to the causes of dissatisfaction. Failure to embark on this leads to an imminent loss of consumers and thus liquidation.

It is pertinent to note that a firm's continuous existence relies on their profit margin and the number of customers/consumers patronizing them. As such, inferences from the study depicts that MTN has a delicate nature of patronage with almost $75 \%$ of their consumers given their educational background which is significantly associated with dissatisfaction. Additionally, business organizations should be conscious of older (aged) consumers as they have the likelihood to be highly dissatisfied. The consciousness of firms should as well 
be extended to consumers with high educational levels, and high religiosity due to the impact of education and religion on the tendency to be highly dissatisfied. Hence, it is important to understand that consumers that acquired tertiary education are easily dissatisfied in different circumstances, sensitize service outcomes and thus fragile. These predicting demographic variables reinforce the present study's conceptualization of consumer dissatisfaction: "a cognitive and affective process in response to a company's service shortfall which is triggered by comparison of expected service performance and actual service performance during or after consumption". Consequently, the study posits that age, educational level, and religion of consumers' underlie their ability to compare expectations and perceived performance. This is achieved via philosophies of life inculcated in consumers through religious teachings, consumers' life experiences gained as adults, and knowledge acquisition via education.

Consumers' ability to compare expected service performance and actual performance which leads to positive or negative disconfirmation could also be determined by the availability of competitor products/services (alternatives), implying that when consumers envisage ostensibly better alternatives, their disconfirmation tend to be affected. Thus, it is reasoned that a high occurrence of irregularities with MTN services without a permanent solution will lead to negative disconfirmation among consumers given the myriad of competitor service providers in the Nigerian telecommunication market. The study concludes that in service sectors, the educational level of consumers is a catalyst of expectancy disconfirmation theory due to its significant association and prediction of dissatisfaction; hence, consumers' ability to understand service policies, service terms and regulations determines their dissatisfaction or/and switching to competitor service tendencies. Therefore, it is instructive for business organizations to observe the demographic trends of their consumers and map out the most suitable strategy to exploit business opportunities before competitor service providers.

\subsection{Recommendations}

Sadly, the study was unable to address every aspect of MTN consumers' dissatisfaction due to the vast nature of the country and the volume of consumers' problems. Hence, the study had some limitations. Among the limitations of this investigation is the inability to generalize the conclusions. This is so because all data were collected in the district of Lagos, and consumers in other cities or villages may offer a divergent view on the services of MTN. Other than that, the investigation was also limited to MTN consumers that were six months old and above of using the service. This was done to capture the minds of old and experienced consumers with MTN service, but it eschewed the opinions of newly subscribed consumers with vital views and information about the services of MTN. Lastly, future studies should test the availability of alternative products/services as a moderator of dissatisfaction.

Further investigations should be conducted to encompass the views of both old and new MTN consumers for a more generalizable result. It should also be extended to other states to improve the generality of the results. There is a need for future researchers to employ a mixed method to enable in-depth investigative findings and to investigate previous dissatisfaction experience as a predictor of high dissatisfaction.

Correspondingly, firms that intend to increase the number of their consumers and extend their market share should:

- Focus on the causes of dissatisfaction and strategize on how to ameliorate the dissatisfaction level among their consumers. Examples of the strategies are promotional offers and giving back to society through high powered consumer-oriented programs. This is because with less dissatisfaction level among consumers, firms are in a better position to gain loyalty and trust, thus continued patronage which will gear them to a positively desired level in the market.

- Handle all consumers' dissatisfaction with caution, more especially consumers that acquired tertiary educational level, older consumers, and consumers with high religiosity. Examples of cautious behaviours towards these classes of consumers are giving them more time and attention to vent their discontents and offering lower tariffs with a minimized level of drop calls.

- Implement consumer-oriented policies that will serve as a repairing mechanism to high dissatisfaction among consumers. Activation of this strategy will in turn foster consumer trust, loyalty and continued patronage by old and new consumers. 


\section{References}

Abubakar, A. (2016). Impact of perceived service quality by mobile telecommunication industry on customer satisfaction in Nigeria. International Journal of Advanced Research, 4(4), 845-852. https://doi.org/10.21474/ijar01/338

Akash, C. (2015). Consumer's Dissatisfaction: Complains, Factors and Disposition. Retrieved from http://www.yourarticlelibrary.com/consumer-behaviour/consumers-dissatisfaction/consumers-dissatisfactio n-complains-factors-and-disposition/64204/.

Al-Doghaither, A. H. (2004). In-patient satisfaction with physician services at King Khalid University Hospital, Riyadh, Saudi Arabia. East Mediterr Health J., 10(3), 358-64.

Anderson, W. E., \& Sullivan, W. M. (1993). The Antecedents and Consequences of Customer Satisfaction for Firms. Marketing Science, 12(2), 125-143. http://dx.doi.org/10.1287/mksc.12.2.125

Azim, T. M., Haque, M. M., \& Chowdhury, R. A. (2013). Gender, Marital Status and Job Satisfaction: An Empirical Study. International Review of Management and Business Research, 2(2), 488-498. Retrieved from http://citeseerx.ist.psu.edu/viewdoc/download?doi=10.1.1.682.2246\&rep=rep1\&type $=$ pdf

Barsky, J. D. (1995). World-Class Customer Satisfaction. Burr Ridge, IL: Irwin Professional Publishing.

Bolton, R. N. (1998). A dynamic model of the duration of the customer's relationship with a continuous service provider: The role of satisfaction. Marketing Science, 17(1), 45-65. Retrieved fromhttp://www.ruthnbolton.com/Publications/RelationshipDurationandSatisfaction.pdf

Chinedu, A. H. (2017). Consumer competency and relationship between dissatisfaction and complaint behavior among mobile telecommunication network consumers in Lagos, Nigeria. T FEM 2017, 1, Universiti Putra Malaysia (UPM) Library.

Chinedu, A. H., Haron, S. A., \& Osman, S. (2016). Competencies of Mobile Telecommunication Network (MTN) Consumers in Nigeria. IOSR Journal of Humanities And Social Science (IOSR-JHSS), 21(11), 61-69. Retrieved from http://iosrjournals.org/iosr-jhss/papers/Vol.\%2021\%20Issue11/Version-4/K2111046169.pdf

Chinedu, A. H., Haron, S. A., \& Osman, S. (2017). Predictors of Complain Behaviour among Mobile Telecommunication Network Consumers. International Journal of Marketing Studies, 9(1), 119-128. https://doi.org/10.5539/ijms.v9n1p119

Cochran, W. G. (1977). Sampling techniques (3rd ed.). New York: John Wiley and Sons.

Daily post Newspaper. (2015). Reps order NCC to stop unsolicited caller tunes and messages. Retrieved from https://dailypost.ng/2015/08/12/reps-order-ncc-to-stop-unsolicited-caller-tunes-messages

Danaher, P. J, and Rust, R. T. (1996). Indirect financial benefits from service quality. Quality Management Journal, 3(2), 63-75. https://doi.org/10.1080/10686967.1996.11918728

Delener, N. (1994). Religious Contrasts in Consumer Decision Behaviour Patterns: Their Dimensions and Marketing Implications. European Journal of Marketing, 28(5), 36-53. Retrieved from http://citeseerx.ist.psu.edu/viewdoc/download?doi=10.1.1.469.747\&rep=rep1\&type=pdf

Donu, K. (2011). Vanguard newspaper; Communication problems. Retrieved from: http://www.vanguardngr.com/2011/04/communication-problems/.

Essoo, N., \& Dibb, S. (2004). Religious Influences on Shopping Behaviour: An Exploratory Study. Journal of Marketing Management, 20, 683-712. https://doi.org/10.1362/0267257041838728

Falilat, A. A., Salman, A., \& Oluwayom, O. O. (2014). Impact of customer satisfaction on mobile telecommunication service providers. Department of Business Administration, University of Ilorin, Ilorin, Nigeria. Retrieved from http://www.transcampus.org/journals; www.ajol.info/journals/jorind

Gerpott, T. J., Rams, W., \& Schindler, A. (2001). Customer retention, loyalty, and satisfaction in the German mobile telecommunications market. Telecommunications Policy, 25(4), 249-269. Retrieved from https://www.deepdyve.com/lp/elsevier/customer-retention-loyalty-and-satisfaction-in-the-german-mobile-3 qWyj0nGLZ

Gloria, K. Q. A. (2011). The Effect of Service Quality on Customer Satisfaction in the Utility Industry-A Case of Vodafone (Ghana). International Journal of Business and Management, 6(5), 203-210. https://doi.org/10.5539/ijbm.v6n5p203

Gr'nhaug, K., \& Johan, A. (1980). Consumer dissatisfaction and Complaining Behaviour as Feedback: A 
comparative analysis of public \& private systems. Advances in consumer Research, 7, 324-328. Retrieved from https://www.acrwebsite.org/volumes/9691/volumes/v07/NA-07

Hair, J. F., Black, W. C., Anderson, R. E., \& Tatham, R. L., (1995). Multivariate data analysis reading. USA: Prentice-Hall, International editions.

Halstead, D., Hartman, D., \& Schmidt, S. L. (1994). Multisource effects on the satisfaction formation process. Journal of the Academy of Marketing Science, 22, 114-29. https://doi.org/10.1177/0092070394222002

Izogo, E. E. (2017). Customer loyalty in telecom service sector: The role of service quality and customer commitment. The TQM Journal, 29(1), 19-36. https://doi.org/10.1108/tqm-10-2014-0089

Jaakkola, E., \& Alexander, M. (2014). The Role of Customer Engagement Behavior in Value Co-Creation: A Service System Perspective. Journal of Service Research, 17(3), 247-261. https://doi.org/10.1177/1094670514529187

Jabulani, N. (2001). An Examination of Customer Service Employees' Self- Efficiency, Job Satisfaction, Demographic Factors and Customer Perception of Hotel Service Quality Delivery in Jamaica, A Dissertation for DBA, Nova South Eastern University.

Kanji, G., \& Moura, P. (2002). Kanji's business scorecard. Total Quality Management, 13(1), 13-27. https://doi.org/10.1080/09544120120098537.

Kim, M. K., Park, M. C., \& Jeong, D. H. (2004). The effects of customer satisfaction and switching barrier oncustomer loyalty in Korean mobile telecommunication services. Telecommunications Policy, 28(2), 145-159. https://doi.org/10.1016/j.telpol.2003.12.003

Kotler, P. (2001). A framework for marketing management. Prentice-Hall.

Kotler, P., \& Keller, K. (2012). Marketing Management (14th ed.). Upper Saddle River, NJ: Prentice-Hall.

Mano, H., \& Oliver, R. L. (1993). Assessing the Dimensionality and Structure of the Consumption Experience: Evaluation, Feeling, and Satisfaction. Journal of Consumer Research, 20(3), 451-466. https://doi.org/10.1086/209361.

Mburu, P. N. (2014). Demographic Statistics, Customer Satisfaction and Retention: The Kenyan Banking Industry. Journal of Business and Economics, 5(11), 2105-2118. https://doi.org/10.15341/jbe(2155-7950)/11.05.2014/015.

Mirzagoll, M., \& Memarian, E. (2015). The effects of demographic factors on customer satisfaction from ATM (Case Study: Mellat Bank in Mazandaran state). Cumhuriyet University Faculty of Science Journal (CSJ), 36(3) 2049-2056. Retrieved from: https://dergipark.org.tr/en/pub/cumuscij/issue/45132/564520

Mobithinking. (2013). Global mobile statistics 2013. Retrieved from http://mobithinking.com/mobilemarketing-tools/latest-mobile-stats

Nigeria Consumer Satisfaction Survey. (2012). Final Report part one (pp. 1-88). Retrieved from https://www.ncc.gov.ng/documents/369-nigeria-consumer-satisfaction-survey-overview/file

Nimako, S. G., \& Ntim, B. A. (2015). Modeling the Antecedents and Consequence of Consumer Switching Intentions in Ghana Mobile Telecommunication Industry. International Journal of Business and Emerging Markets, 7(1), 37-75. $\quad$ Retrieved from https://www.academia.edu/24473677/Modelling_the_antecedents_and_consequence_of_consumer_switchi ng_behaviour_in_Ghanaian_mobile_telecommunication_industry

Nischay, K., Sankpal, S., \& Upamannyu, K. N. (2014). Effect of brand image on customer satisfaction \& loyalty intention and the role of customer satisfaction between brand image and loyalty intention. Journal of social science research, 3(2), 274-285.

Oliver, R. L. (1980). A cognitive model of the antecedents and consequences of satisfaction decision. Journal of Marketing Research, 17, 460-469. Retrieved fromhttps://www.jstor.org/stable/3150499

Oliver, R. L. (1997). Satisfaction: A Behavioral Perspective on the Consumer. New York: McGraw-Hill.

Pallant, J. (2011). A step by step guide to data analysis using SPSS (4th ed.).

Patrick-Akpan, J. (2018). Employee empowerment and customer satisfaction in Nigeria's banking industry (Order No. 10784518). ProQuest Dissertations \& Theses Global. (2031128287). Retrieved from https://search.proquest.com/docview/2031128287?accountid=27932 
Ranjit, K. (2011). Research methodology: A step by step guide for beginners (3rd ed.). SAGE publication limited.

Reidenbach, R. E., \& Robin, D. P. (1990). Toward the Development of a Multidimensional Scale for Improving Evaluations of Business Ethics. Journal of Business Ethics, 9(8), 639-653. Retrieved from https://www.jstor.org/stable/25072080

Samuel, N. O., \& Olatokun, W. (2014). Telecommunication Services Provision in Nigeria: Consumers' Perspectives on Information Provision, Advertising and Representation of Services. Afr J. of Comp and ICTs, 7(5), 63-76. Retrieved from https://www.ideals.illinois.edu/handle/2142/88828

Sathish, M., Kumar, K. S., Naveen, K. J., \& Jeevanantham, V. (2011). A Study on Consumer Switching Behaviour in Cellular Service Provider: A Study with reference to Chennai. Far East Journal of Psychology and Business, 2(2), 71-81. Retrieved from https://Econpapers.repec.org/RePEc:fej:articl:v:2b:y:2011:i:5:p:71-81.

Serin, A. E., Balkan, M. O., \& Dogan, H. (2013). The effects of demographic factors on perceived customer satisfaction between public and private banks: Turkey example. International Journal of Information Technology and Business Management, 22(1), 1-7.

Timothy, E. M. (2015). Daily post newspaper. Reps order NCC to stop unsolicited caller tunes. Retrieved from http://dailypost.ng/2015/08/12/reps-order-ncc-to-stop-unsolicited-caller-tunes-messages/

Turel, O., \& Serenko, A. (2006). Satisfaction with mobile services in Canada: An empirical investigation. Telecommunications Policy, 30(5-6), 314-331. https://doi.org/10.1016/j.telpol.2005.10.003

Westbrook, R. A., \& Oliver, R. L. (1981). Developing better measures of consumer Satisfaction: Some Preliminary Results. Advances in Consumer Research, 8, 94-99. Retrieved from https://www.acrwebsite.org/volumes/9791

\section{Copyrights}

Copyright for this article is retained by the author(s), with first publication rights granted to the journal.

This is an open-access article distributed under the terms and conditions of the Creative Commons Attribution license (http://creativecommons.org/licenses/by/4.0/). 